услуг (работ), выполненной каждой стороной, заказанному суммарного объему услуг (работ), то задача оптимизации считается решенной, и найденные объемы являются оптимальными. Если такое условие не выполняется, то оптимальные значения находятся с помощью функции Лагранжа.

Полученные оптимальные объемы прямопропорциональны суммарному объему услуг (работ). При большем Q каждая из сторон будет более конкурентоспособной при предоставлении (выполнении) данных услуг (работ).

\section{СПИСОК ЛИТЕРАТУРЫ}

1. Совершенствование управления морскими торговыми портами: Учебное пособие / В.И.Чекаловец, А.Л.Колодин, Г.П.Столяров, Е.В.Меркт, Н.Г.Гребенник, И.М.Олефир, Е.Г.Пустовит, Н.В.Яровая Одесса: ОНМУ, 2002. - 142 с.

2. Lacity M. Business process outsourcing and dynamic innovation / Mary Lacity, Leslie Willcocks // Strategic Outsourcing: An International Journal, Vol. 7 Iss:
1, pp.66 - 92 [Электронный ресурс]. - Режим доступа:

http://www.emeraldinsight.com/doi/full/10.1108/ SO-11-2013-0023

3. Тыртышный Н.Н. Аутсорсинг как инструмент уменьшения логистических рисков / Н.Н. Тыртышный // Инженерный вестник Дона. - Выпуск №2. Том20, 2012. - С. 294-298.

4. Аутсорсинг в сфере грузовой и коммерческой работы: учеб. пособие / М.В. Нечипорук. - Хабаровск: Изд-во ДВГУПС, 2014. $-81 \mathrm{c}$.

5. Pierre Cariou. Outsourcing ship management: Implications for the logistics chain / Pierre Cariou, Fran,cois-Charles Wolf // Lemna, 2011 [Электронный ресурс]. - Режим доступа: https://hal.archives-ouvertes.fr/hal-00593742/ document

6. Selective outsourcing [Электронный pecypc]. - Режим доступа: http://www.portstrategy .com/news101/portoperations/cargo-handling/selective_outsourcing

7. Ефимова Е.Г. Экономика: Учебное пособие / Е.Г. Ефимова. - М.: МГИУ, 2005. $368 \mathrm{c}$.

Рецензент д.е.н., професор ОНМУ Жихарєва В.В. Експерт редакційної колегії к.е.н., доцент УкрДУЗТ Зубенко В.О.

УДК: 339.47:656.2

\title{
СИСТЕМА ЕКОНОМІЧНОЇ БЕЗПЕКИ ПІДПРИЕМСТВ ЗАЛІЗНИЧНОГО ТРАНСПОРТУ
}

\author{
Чередниченко О.Ю., к.е.н., доцент (УкрДУЗТ)
}

В статті розкрито основні завдання управління економічною безпекою на підприсмствах залізничного транспорту. Сформульовано принципи забезпечення економічної безпеки, визначено об'єкти і суб'єкти системи забезпечення економічної безпеки залізниць. У зв'язку з важливістю реалізації превентивних заходів розкрито зміст стратегії економічної безпеки, обтрунтовано перспективний підхід до організачії діяльності із забезпечення економічної безпеки та визначено комплекс необхідних заходів.

Ключові слова: система, економічна безпека, принципи, підходи до організацій, підприємства залізничного транспорту. 


\title{
СИСТЕМА ЭКОНОМИЧЕСКОЙ БЕЗОПАСНОСТИ ПРЕДПРИЯТИЙ ЖЕЛЕЗНОДОРОЖНОГО ТРАНСПОРТА
}

\author{
Чередниченко А.Ю., к.э.н., доцент (УкрГУЖТ)
}

\begin{abstract}
В статье раскрыты основные задания управления экономической безопасностью на предприятиях железнодорожного транспорта. Сформулированы принципы обеспечения экономической безопасности, определены объекты и субъекты системы обеспечения экономической безопасности железных дорог. В связи с важность реализации превентивных мероприятий раскрыто содержание стратегии экономической безопасности, обосновано перспективный подход $\kappa$ организации деятельности по обеспечению экономической безопасности и определен комплекс необходимых мероприятий.
\end{abstract}

Ключевые слова: система, экономическая безопасность, принципы, подходы к организации, предприятия железнодорожного транспорта.

\section{SYSTEM OF ECONOMIC SECURITY OF ENTERPRISES OF RAILWAY TRANSPORT}

\section{Cherednichenko O.U., Candidate of Economic Sciences, associate professor (USU of RT)}

In the article are disclosed the basic tasks of management of economic safety of the enterprises of railway transport. Formulated the principles of economic security, defined objects and subjects of the system of economic security of the Railways. To ensure the comprehensiveness and objectivity of the evaluation of economic security of enterprises of the railway sector is proposed to distinguish two types of objects: firstly, that the resources and reserves of increase of efficiency of activity; secondly, it is business processes, including processes of formation and reproduction of resources. In connection with the importance of implementing preventive measures are disclosed the content of strategy of economic security, proved a perspective approach for the organization of activities on ensuring economic security, which is based on hierarchically-component principle. Defined a set of priority measures to ensure economic security for personnel, information analysis, financial-economic, legal, technological and resource areas.

Keywords: system, economic security, principles and approaches to organizations, enterprises of railway transport.

Постановка проблеми та ї̈ зв'язки з науковими чи практичними завданнями. Залізничний транспорт Україні $є$ одним 3 головних складових транспортнокомунікаційної системи країни, що відіграє виключно важливу роль в розвитку економіки, оскільки, здійснюючи перевезення вантажів відповідно до потреб виробництва, забезпечує нормальне функціонування і розвиток всіх галузей, регіонів і підприємств. Залізничний транспорт як життєвоважлива галузь господарства забезпечує економічну безпеку і цілісність держави.

В останні роки умови функціонування залізничного транспорту погіршилися у зв'язку зі складною політичною та економічною ситуацією в країні, спадом вітчизняного виробництва. Також загрозливих масштабів набули внутрішні проблеми залізничної галузі. Негативний вплив зовнішніх та внутрішніх факторів обумов зниження фінансової стійкості залізничного транспорту, вже в 1 півріччі 2014 року Укрзалізниця зазнала збитків на 8,2 млрд. грн і має борги 16,4 млрд. грн кредитів, 3,6 млрд. грн фінансового лізингу та інші, в результаті було оголошено технічний дефолт. Зазначене свідчить, що реалізація економічних інтересів підприємств залізничної галузі вимагає вирішення завдання в області забезпечення їх економічної безпеки.

Аналіз останніх досліджень $i$ публікацій. Різноманітні аспекти забезпечення економічної безпеки на різних рівнях економіки досліджують в своїх працях такі вчені як: О.В Ареф'єва, М. Бендиков, 
А.В. Козаченко, В.П. Пономарев, А.Н. Ляшенко, В.I. Мунтіян, В.С. Понамаренко, Т.С. Клебанова, Н.Л. Чернова, А.В. Козаченко, В.П. Пономарев, А.Н. Ляшенко, Д.І. Ковальов, Т.Г. Сухорукова, М.В. Куркін [1-7].

Вчені-фахівці в галузі залізничного транспорту В.Л. Дикань, І.В. Воловельська, О.В. Маковоз, І.Л. Назаренко, С.В. Каламбет, В.А. Воропай, Р.О. Кожевніков, З.П. Межох, Н.П. Терьошина, В.А. Персіанов, С.П. Міщенко, Т.О.Тимофєєва [8-14] присвятили свої праці вирішенню проблем економічної безпеки на підприємствах залізничної галузі, у тому числі питанням визначення загроз i ризиків економічної безпеки, підходам до їх оцінювання та пошуку інструментів управління економічною безпекою.

Виділення невирімених частин загальної проблеми. Поряд 3 значними напрацюваннями у сфері забезпечення економічної безпеки потребують подальшого вивчення питання формування системи економічної безпеки на підприємствах залізничного транспорту.

Формування цілей статmі. Метою статті $\epsilon$ розкриття основних складових системи економічної безпеки підприємств залізничної галузі.

Виклад основного матеріалу. Галузь залізничного транспорту як об'єкт вивчення $\epsilon$ складною виробничо-економічною i соціальною системою зі своєю внутрішньою, тільки їй властивою територіальновиробничою і функціональною структурою. Враховуючи, що система - це сукупність об'єктів, взаємодія яких обумовлює наявність інтеграційних якостей, не властивих іiі компонентам, то якраз по лініях внутрішніх і зовнішніх зв'язків системи i можуть реалізуватися загрози ії економічної безпеки. Для забезпечення максимального ступеня захисту від цих загроз і необхідна певна діяльність, яка також повинна носити системний характер.

Накопичений досвід показує [8, 13], що забезпечення економічної безпеки - це безперервний процес, що полягає в обгрунтуванні й реалізації найбільш раціональних форм, методів, способів і шляхів створення, вдосконалення, розвитку системи безпеки, безперервному управлінні нею,

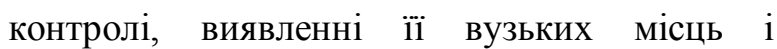
потенційних загроз виробничо-господарській діяльності підприємств залізничного транспорту.

Найважливішими задачами в області забезпечення економічної безпеки підприємств залізничної галузі слід визначити:

- забезпечення захищеності

виробничо-господарської діяльності підприємств залізничного транспорту від дії несприятливих зовнішніх i внутрішніх чинників;

- своєчасне прогнозування і виявлення зовнішніх i внутрішніх загроз економічної безпеки залізниць;

- здійснення оперативних i довгострокових заходів по попередженню i локалізації загроз;

- створення системи злагодженого функціонування і взаємодії всіх структурних підрозділів залізниць для вирішення питань забезпечення економічної безпеки;

- формування структури господарського комплексу залізничного транспорту, відповідно до програми структурної реформи на залізничному транспорті;

- оновлення основних виробничих фондів, виробничого потенціалу і технологій, що забезпечують високий технічний рівень виробництва i підвищення конкурентоспроможності транспортних послуг;

- підвищення ефективності використовування майнового комплексу, збільшення всіх видів доходів;

- посилення інвестиційної та інноваційної активності, збільшення частки інвестицій в основний капітал;

- відновлення i розвиток нових регіональних зв'язків;

- формування сприятливого ділового $\mathrm{i}$ підприємницького клімату;

- зростання добробуту працівників залізниць;

$\begin{array}{llr}\text { - забезпечення } & \text { контролю за } \\ \text { раціональним } & \text { використовуванням }\end{array}$ матеріально-виробничих ресурсів;

- збалансоване дотримання галузевих інтересів залізничного транспорту і інтересів залізниць; 
запобігання

навколишнього середовища.

Організація і функціонування системи забезпечення економічної безпеки в цілях максимальної ефективності повинні грунтуватися на ряді наступних принципів [3, 5, 8, 14]: законність; економічна доцільність; поєднання превентивних і реактивних заходів; обгрунтованість; комплексність; координація і взаємодія; безперервність; активність; плановість; диференційованість; підконтрольність; компетентність; поєднання гласності і конфіденційності; вдосконалення.

Об'єкт і суб'єкт системи забезпечення економічної безпеки тісно взаємопов'язані. Об'єктом системи в цілому виступає економічний потенціал i виробничогосподарська діяльність підприємств залізничного транспорту в поточному i перспективному періоді. Конкретними ж об'єктами захисту виступають ресурси: фінансові, техніко-технологічні, матеріальні, інформаційні, кадрові та інші.

В останній час посилюється кримінологічна складова економічної безпеки залізничного транспорту, загрозами якої $\epsilon$ злочинні та терористичні дії, різноманітні правопорушення, а об'єктами впливу транспортна система, майно підприємств залізничного транспорту та вантажовласників, життя, здоров'я і права пасажирів та працівників.

Вважаємо, що для забезпечення комплексності і об'єктивності оцінки стану економічної безпеки підприємств залізничної галузі слід розрізняти два типи об'єктів: поперше, це ресурси та резерви підвищення ефективності діяльності; по-друге, це бізнеспроцеси, у тому числі і процеси формування та відтворення ресурсів.

Суб'єкт системи забезпечення економічної безпеки носить складніший характер, оскільки його діяльність обумовлюється не тільки особливостями i характеристиками об'єкту, але і специфічними умовами зовнішнього середовища, яке його оточує. Виходячи 3 цього, можна виділити дві групи суб'єктів, що забезпечують економічну безпеку: зонішні суб'єкти; внутрішні суб'єкти.

До зовнішніх суб'єктів відносяться органи законодавчої, виконавчої i судової влади. Ці органи формують законодавчу основу функціонування і захисту виробничогосподарської діяльності в різних іï аспектах і забезпечують іiі виконання.

До внутрішніх суб'єктів відносяться особи, безпосередньо здійснюючі діяльність із захисту економічної безпеки.

Суб'єкти, що забезпечують економічну безпеку, здійснюють свою діяльність на основі певної стратегії і тактики.

Загальновідомо, що стратегія - це довгостроковий план досягнення мети, i відповідно до цього, генеральна стратегія економічної безпеки виражається через загальну концепцію комплексної системи забезпечення економічної безпеки підприємницької діяльності.

Крім генеральної стратегії виділяються також спеціальні стратегії. Нарешті, можуть застосовуватися функціональні стратегії безпеки.

Стратегія економічної безпеки включає, перш за все, систему превентивних заходів, що реалізовуються через регулярну, безперервну, роботу по перевірці контрагентів, аналізу передбачуваних операцій, експертизі документів, виконанню правил роботи з конфіденційною інформацією i т.п. Служба безпеки в цьому випадку виконує роль контролера.

Стратегія реактивних заходів, що застосовується у разі виникнення або реального здійснення яких-небудь загроз економічній безпеці підприємництва заснована на застосуванні ситуаційного підходу та обліку всіх зовнішніх і внутрішніх чинників. Вона реалізується службою безпеки через систему заходів, специфічних для даної ситуації.

У функціональному розрізі будь-якій системі забезпечення економічної безпеки властиві:

розробка нормативно-правової бази, що $\epsilon$ структурним компонентом системи забезпечення економічної безпеки даного об'єкту, а також iї постійне вдосконалення при зміні умов функціонування цього об'єкту;

накопичення, обробка i аналіз інформації про умови функціонування даного об'єкту, особливо про наявність, склад, ступінь реальності i інші характеристики загроз, тобто моніторинг умов, який бажано здійснювати безперервно; 
розробка критеріїв i індикаторів економічної безпеки об'єкту, а також методів оцінки рівня його захищеності, що дозволяють формувати науково обгрунтований механізм протидії загрозам; розробка концепції економічної безпеки об'єкту і довгострокової стратегії іiі забезпечення, a також періодичне їх оновлення при зміні умов функціонування; коротко- i середньострокове планування діяльності 3 забезпечення економічної безпеки даного об'єкту, що витікає з згаданих концепції і стратегії;

встановлення необхідної взаємодії між всіма органами, що в тому або іншому ступені беруть участь в забезпеченні економічної безпеки, 3 метою чіткого розмежування функцій і зон відповідальності, більшого взаєморозуміння, встановлення тісних робочих контактів, недопущення розпиленості сил, паралелізму, ненавмисного створіння взаємних перешкод;

повсякденна робота 3 забезпечення економічної безпеки, заснована на планах.

Закордонній досвід [15] свідчить про те, що існує декілька підходів до організації системи економічної безпеки.

Перший підхід - «системний» - для кожного елемента бізнесу створюється система i послідовно поліпшується. Наприклад, система управління інвестиціями, система управління персоналом i так далі. Згідно цього підходу, будь-яка система економічної безпеки повинна містити ряд елементів: внутрішнє середовище; система оцінки і реагування на ризики; контрольні процедури; інформаційні потоки; комунікаційні потоки; система моніторингу.

Другий підхід заснований на оцінці ризиків - аналізуємо ризики підприємства i починаємо управляти спочатку тими, які спричиняють найбільшу дію. Звідси і витікає склад елементів системи економічної безпеки - в розрізі ризиків.

Зважаючи на те, що основне значення системи економічної безпеки підприємств залізничного транспорту полягає в тому, що вона повинна носити попереджуючий характер, а основними критеріями оцінки іï надійності та ефективності $\epsilon$ забезпечення стабільної роботи, збереження і примноження фінансів i матеріальних цінностей та попередження кризових ситуацій, доцільним стає побудова системи економічної безпеки за ієрархічно-компонентним принципом по функціональним внутрішньогосподарського підсистемам механізму підприємств залізничного транспорту.

Основними групами заходів, які мають здійснюються керівництвом в процесі управління економічною безпекою, є такі: кадрові - система заходів для усунення ризиків в зв'язку 3 володінням певною частиною персоналу інформацією, що може розцінюватися як комерційна таємниця, недостатнім кваліфікаційно-освітнім рівнем працівників, помилками та зловживаннями (керування кадровими ризиками, вдосконалення кадрових технологій); інформаційно-аналітичні - система заходів, що проводяться 3 метою прийняття ефективних та дієвих управлінських рішень, що стосуються стратегії і тактики розвитку підприємства; прийняття превентивних заходів і попередження реальних та можливих погроз економічній безпеці;

фінансово-економічні - система заходів, до яких належать: забезпечення економічної ефективності господарської діяльності суб'єкта господарювання; забезпечення фінансової стабільності та фінансової незалежності; забезпечення високої конкурентноздатності послуг на основі ефективного менеджменту та маркетингу;

правові - дії, спрямовані на відслідкування нових законодавчих актів, що приймаються у сфері економічної безпеки та їх активне застосування;

техніко-технологічні - заходи, спрямовані на досягнення відповідного рівня освоєння виробничої потужності, інноваційну політику підприємства, своєчасне оновлення основних виробничих фондів тощо;

ресурсні - система заходів, що проводяться 3 метою забезпечення виробництва основними ресурсами.

Висновки. Таким чином, труднощі, які впливають на залізничний транспорт в теперішній час, потребують від підприємств галузі створення дієвої системи забезпечення економічної безпеки. Остання має представляти собою комплекс взаємопов'язаних заходів організаційноправового, економічно-мотиваційного та техніко-технологічного характеру, 
направлених на захист життєво важливих інтересів залізниць від загроз, котрі можуть призвести до істотних економічних втрат та кризових ситуацій.

\section{СПИСОК ЛІТЕРАТУРИ}

1. Ареф'єва О. В. Наукові основи формування економічної безпеки підприємств / О. В. Ареф'єва // Недержавна система безпеки підприємства як суб'єкт національної безпеки України : збірник матеріалів наук.практ. конф. ; Київ, 16-17 травня 2001 р. - К. : Вид-во Європейського ун-ту фінансів, інформаційних систем, менеджменту і бізнесу, 2003. - C. 49-53.

2. Бендиков М. Экономическая безопасность промышленного предприятия (организационно-методический аспект) / М. Бендиков // Консультант директора. - 2000. № 2. - C. 7-13.

3. Козаченко А. В. Экономическая безопасность предприятия: сущность и механизм обеспечения / А. В. Козаченко, В. П. Пономарев, А. Н. Ляшенко- К.: Либра, 2003. $-280 \mathrm{c}$.

4. Ковальов Д. Економічна безпека підприємства / Д. Ковальов, Т. Сухорукова // Економіка України. - 2005. - № 10. - С. 48-56.

5. Куркин Н.В. Управление экономической безопасностью развития предприятия: монография / Н. В. Куркин. Днепропетровск: АРТ-ПРЕСС, 2004. - 450 с.

6. Мунтіян B.I. Економічна безпека України / В.І. Мунтіян. - К.: КВІЦ, 1999. - 463 c.

7. Понамаренко В.С. Економічна безпека регіону: аналіз, оцінка, прогнозування: монографія В.С. Пономаренко, Т.С. Клебанова, Н.Л. Чернова. - Харків: ИД «ИНЖЕК», 2004. $144 \mathrm{c}$.

8. Дикань В.Л. Економічна безпека підприємства: навч. посібник. / В.Л. Дикань, І.В. Воловельська, О.В. Маковоз. - Харків: УкрДАЗТ, 2011. - 266с.

9. Дикань, В.Л. Комплексна методика визначення рівня економічної безпеки, оцінки ризиків та ймовірності банкрутства підприємства : монографія / В.Л. Дикань, І.Л. Назаренко; Українська державна академія залізничного транспорту - Харків: УкрДАЗТ, 2011. - 142 c.

10. Каламбет С.В. Механізм забезпечення економічної безпеки підприємств залізничної галузі / C.В. Каламбет, В.А. Воропай // Науковий вісник: Фінанси, банки, інвестиції - 2013 - №2 С. 106113.

11. Кожевников Р .А. Экономическая безопасность железнодорожного транспорта : учебное пособие для вузов железнодорожного транспорта / Р .А. Кожевников, 3. П. Межох, Н.П. Терешина. - М. : Маршрут, 2005. - 326 с.
12. Міщенко С.П. Напрями забезпечення економічної безпеки залізничного транспорту / С.П. Міщенко / Вісник економіки транспорту та промисловості. -2011. - № 34. - С. 206-209.

13. Персианов В.А. Железнодорожный транспорт и экономическая безопасность России / В.А. Персианов// Вестник университета. - Сер. Управление на транспорте. - М: ГУУ, 2001. - № 1. - С. 5-9.

14. Тимофєєва Т. О. Розробка механізму щодо забезпечення економічної безпеки залізничного транспорту : автореф. дис. на здобуття наук. ступеня канд.екон. наук : спец. 08.00.03 "Економіка та упр. нац. госпвом" / Тимофєєва Тетяна Омельянівна ; Укр. держ. акад. залізн. трансп. - Х., 2009. - 20 с.

15. Mei F. D. Research on Enterprise Security Management Mode Based on Animation Technology / F. D.Mei, J. J. Hou, Z. H. Mei // Applied Mechanics and Materials. - 2013. Vol. 307. - P. 482- 487.

Рецензент д.е.н., профресор УкрДУЗТ Кірдіна О.Г. Експерт редакційної колегї к.е.н., дочент УкрДУЗТ Токмакова І.В.

Вісник економіки транспорту і промисловості № 51, 2015 